\title{
Assessment of Physico-chemical Processes for Treatment and Reuse of Greywater
}

\author{
H.I. Abdel-Shafy ${ }^{\left({ }^{*}\right)}$ and A. M. Al-Sulaiman ${ }^{(2,3)}$ \\ ${ }^{(1)}$ Water Research \& Pollution Control Dept., National \\ Research Centre, Dokki, Cairo, Egypt, ${ }^{(2)}$ Ministry of Higher \\ Education \& Scientific Research, Qadisiyah University, Iraq and \\ ${ }^{(3)}$ Sanitary \& Environmental Department, Faculty of Engineering, \\ Cairo University, Giza, Egypt.
}

$\mathbf{T}$ HE PRESENT study deals with real greywater that was collected from five flats and connected to a pilot plant. The research study aims at evaluation of greywater treatment and reuse using diverse phico-chemical treatment process including sedimentation, coagulation/flocculation and Fenton`s reaction. The study includes the evaluation of different settling times using two successive sedimentation tanks that received raw greywater. The chemical coagulation phase includes lime and lime aided with ferric chloride as well as advanced oxidation (as Fenton's reaction). The experimental method involves monitoring of specific water quality constituents, under varying operating conditions, at different sedimentation periods and different chemicals doses to reach the sustainable approach. Greywater treatment was examined first in batch experiments to determine the optimum operating conditions including: the settling time, the dose of lime $(\mathrm{CaO})$, ferric chloride $\left(\mathrm{FeCl}_{3}\right)$, and Fenton's reaction $\left[\mathrm{Fe}_{2}\left(\mathrm{SO}_{4}\right)_{3} \cdot \mathrm{H}_{2} \mathrm{O}_{2}\right]$. The obtained optimum conditions were implemented throughout the pilot plant investigation.

The pilot plant study was performed at a settling time of $3.0 \mathrm{hr}$, the removal rates shifted from the initials 64.5, 30.1, 19.4 and $31.7 \%$ to $71.3,25.5,29.6$ and $49.1 \%$ for the TSS, COD, $\mathrm{BOD}_{5}$ and oil \& grease, respectively. Such treatment was not sufficient to reach the characteristics of non-restricted reuse. By increasing the settling time to $4.5 \mathrm{hr}$, better removal efficiency could be achieved namely; $66.5 \%$, $40.3 \%, 38.5 \%$, and $50.2 \%$, successively. To enhance the treatment efficiency of the above system; lime was added at $160 \mathrm{mg} / \mathrm{l}$ where the characteristics of the final effluent could cope with the permissible level of the $2^{\text {nd }}$ group (secondary wastewater treatment) for irrigation reuse according to the "Egyptian Guideline". Combination of chemical treatment using lime $(160 \mathrm{mg} / \mathrm{l})$ aided with ferric chloride (100 mg/l) with sedimentation (4.5 hours) was carried out. The obtained results showed that the removal rates of TSS, COD, BOD and oil \& grease enhanced to 94.9, 91.8, 94.2 and 97.2\%, successively. The E. coli count and the number of cells or eggs of Nimatoda in the final effluent reached $100 / \mathrm{ml}$ and 1 count $/ \mathrm{l}$, respectively. The final effluent could cope with the permissible level, $1^{\text {st }}$ Class (advanced wastewater treatment), for non-restricted water

\footnotetext{
*Email: hshafywater@yahoo.com
} 
reuse according to the "Egyptian Guideline for wastewater reuse". Present study proves that chemical coagulation could successfully approach the objectives of treatment while mutually saves space, energy and labors.

Keyword: Greywater treatment, Water reuse, Sedimentation, Chemical coagulation, Lime, Ferric chloride and Fenton's reaction.

Treatment of greywater can range from simple coarse filtration ${ }^{(1)}$ to advanced biological treatment ${ }^{(2)}$. Previous studies suggested that biological processes should be preferred due to the high levels of organics in the water ${ }^{(3,4)}$ including constructed wetland $^{(5,6)}$. The major difference between different technologies is the level of suspended solids and microorganism removal. In comparison, direct physical processes are common at very small scale for the removal of suspended solids, but are less effective for organics removal ${ }^{(4,7)}$.

Most greywater treatment plants include a one or two-step septic-tank for pretreatment ${ }^{(2)}$. Currently, most greywater treatment systems installed are based on septic tanks in combination with constructed wetlands ${ }^{(8,9)}$. The greywater treatment needs both physical and biological processes for removal of particles, dissolved organic-matter and pathogens ${ }^{(10,11)}$. Only few studies on chemical treatment of greywater are available. On the other hand, chemical coagulation proved to be very effective in the removal of suspended solids and precipitation of heavy metals ${ }^{(12,13)}$. Therefore, combination of chemical treatment with sedimentation could be very effective. An important feature of such combination is the advantage of operating at a short hydraulic retention time (HRT) as well as effective sludge precipitation and the possibility to combine the removal of $\mathrm{BOD} / \mathrm{COD}^{(14,15)}$.

Using coagulation and sedimentation improves the removal of the colloidal suspended solids from wastewater ${ }^{(12)}$. The coagulants used included aluminium sulfate, ferric sulfate, lime, and/ or ferric chloride. Alum and ferrous sulfate showed better turbidity removal than that of the lime and ferric chloride. A mixture of alum and ferric chloride could achieve better removal of all the colloidal suspended solids. It was found that the aeration of the coagulated and settled samples improved the COD removal efficiently than the samples that were not coagulated by about $41 \% .^{(12,16,17)}$.

Recently, ferric chloride was tested as coagulant for the treatment of wastewater using bench- scale investigation ${ }^{(12,18)}$. The study proved that $38 \%$ decrease of the organic load was achieved, where the effluents were low in organic content, suspended matter and colloids ${ }^{(19)}$.

Egypt. J. Chem. 57, No. 3 (2014) 
Aluminium sulphate and ferric chloride were used as coagulant and coagulant aid. The COD and chromium were removed mainly through coagulation: 38-46\% removal of suspended solids, 30-37\% removal of total COD from settled tannery wastewaters and 74-99\% removal of chromium at an initial concentration of 12 $\mathrm{mg} / \mathrm{l}$. The optimum coagulant dosage was $800 \mathrm{mg} / \mathrm{l}$ at $\mathrm{pH}$ around $7.5^{(20)}$.

Rubi et al. (2009) ${ }^{(21)}$ studied the treatment of wastewater discharged from four car washing water. The study included sedimentation and coagulation. The effects of the coagulants Servical P (aluminium hydroxyl chloride), Servican 50 (poly-diallyldimethyl ammonium chloride), aluminium sulphate and ferric chloride were evaluated. The achieved removal using sedimentation was $82 \%$, $88 \% 73 \%$ and $51 \%$ for oils, total suspended solids, COD and turbidity, respectively. In the treatment by coagulation they achieved average efficiencies nearly to $74 \%$ for COD removal, greater than $88 \%$ in the case of total suspended solids removal and $92 \%$ in the case of turbidity and except the performance of Servican 50 greater than $90 \%$ in oil removal.

Some of the additional advantages of employing ferric or aluminium salts in wastewater treatment are: precipitation of sulphur compounds, easier sludge dewatering and increased efficiency of pollutants elimination. Meanwhile, reduction in energy consumption that is used for the biological process was also achieved ${ }^{(22)}$. The disadvantage is the relative increase in the sludge volume. In addition, large amounts of chemicals should be transported to the treatment location and polymers used can be expensive ${ }^{(23)}$.

It was found that Fenton process using ferrous sulphate could remove between $45 \%$ and $49 \%$ of the COD in low-range greywater. The photo-Fenton process achieved $83 \%$ COD removal ${ }^{(24)}$.

This work aims to increase the efficiency of the sedimentation process by employing chemical treatment in combination with settling system. The chemical treatment includes coagulation (lime only, ferric chloride aided with lime) or advanced oxidation (Fenton's reaction) followed by sedimentation. The experimental method involves monitoring of specific water quality constituents under varying operating conditions and correlating between the different treatments systems. The final effluent could be discharged safely to the waterways or to be reused for irrigation according to the EEAA ${ }^{(25)}$.

\section{Material and Methods}

\section{Source of raw greywater}

Real greywater is the subject of the present study. To obtain a real greywater, municipal wastewater was separated from the origin into Black (B), Grey (G) and Yellow (Y) water as segregated and collected from one house across the Training Demonstration Centre (TDC) site in the National Research Centre (NRC), Cairo, Egypt. One side of this house that consists of five apartments is 
presently connected to the TDC site as separated B, G and Y water manholes. The collected greywater $(\mathrm{G})$ includes wastewater from baths, showers, handwash basins, washing machines, dishwashers and kitchen sinks. The schematic diagram of the greywater route to the pilot-plant is illustrated in Fig. 1.

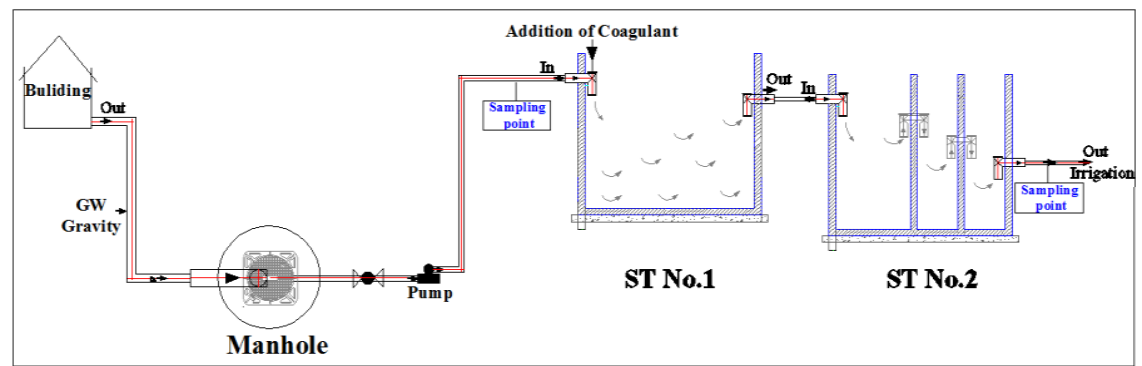

Fig. 1. The schematic diagram of the greywater route to the pilot-plant and the treatment system (side view).

The present study was carried out in both bench- and pilot plant scales (Fig. 2).

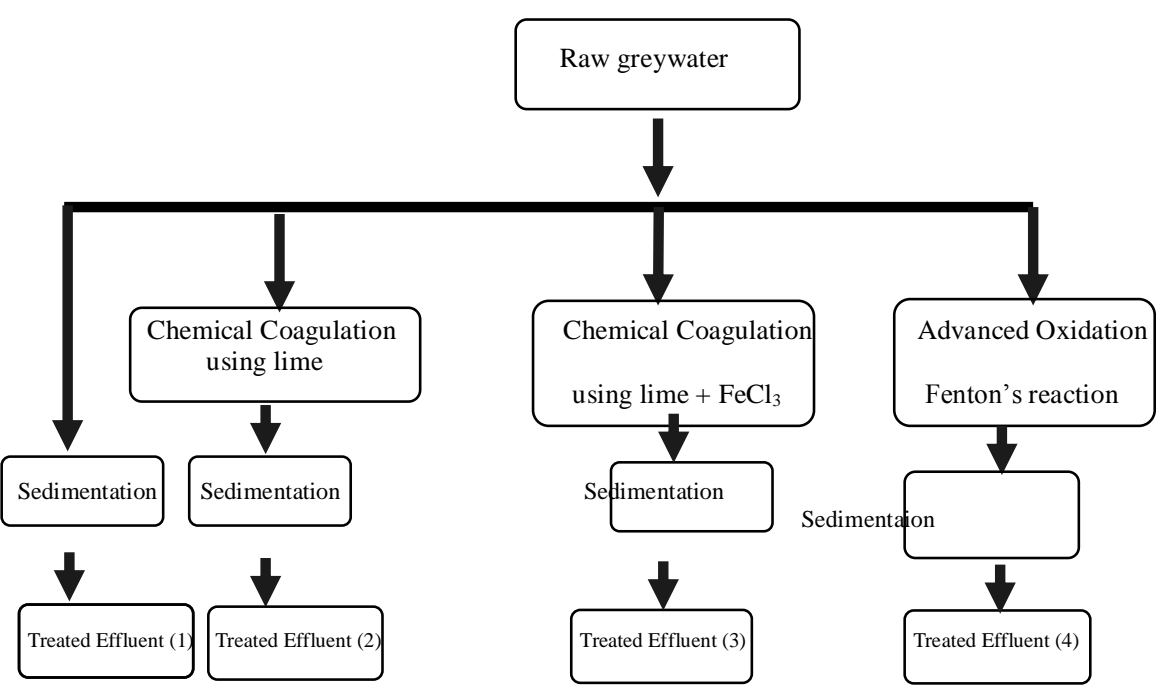

Fig. 2. Schematic diagram of the treatment system.

Bench-scale investigation

The experiments were conducted in a jar-test apparatus at room temperature. Batch reactors consist of flash mix at speed of $300 \mathrm{rpm}$, flocculation for $20 \mathrm{rpm}$ followed by settling for $30 \mathrm{~min}$.

Determination of optimum chemical coagulant dose

The examined chemical coagulants were lime and lime aided with ferric chloride. Determination of the lime optimum dose was carried out. The

Egypt. J. Chem. 57, No. 3 (2014) 
examined lime dose ranged from 5 to $200 \mathrm{mg} / \mathrm{l}$. Further, an investigation was carried out to determine the optimum dose of ferric chloride to the predetermined lime optimum dose. The examined ferric chloride dose ranged from 10 to 120 $\mathrm{mg} / \mathrm{l}$.

Determination of optimum advanced oxidation dose

Fenton's reaction as presented by hydrogen peroxide and ferric sulfate was examined. The advanced oxidation consists of ferric sulfate dose ranged from 50 to $800 \mathrm{mg} / \mathrm{l}$, whereas examined hydrogen peroxide dose ranged from 5 to 130 $\mathrm{mg} / \mathrm{l}$.

Pilot -plant continuous system

The treatment train is illustrated in the schematic diagram (Fig. 2). Four treatment approaches were investigated as follows:

The $1^{\text {st }}$ approach is settling the raw greywater in the settling tank (Fig. 3) in absence of any chemicals,

the $2^{\text {nd }}$ approach is receiving the raw greywater, thereafter adding the predetermined lime dose followed by settling,

the $3^{\text {rd }}$ approach is receiving the raw greywater, thereafter adding the predetermined lime dose and ferric chloride doses followed by settling,

the $4^{\text {th }}$ approach is receiving the raw greywater, thereafter adding the predetermined advanced oxidation (Fenton's reaction) followed by settling.

\section{Sedimentation tank}

Two-step process of successive sedimentation tanks was applied as pretreatment phase to remove larger particles, hair, oil and grease (Fig. 3). Effluent of the sedimentation tanks was then directed to irrigation purposes (Fig. 1).

The two sedimentation tanks are made of polyvinyl chloride (PVC) with a working volume of $0.7 \mathrm{~m}^{3}$ each (Fig. 3). The dimension of each tank is: $1.00 \mathrm{~m}$ height, $0.90 \mathrm{~m}$ width and $1.00 \mathrm{~m}$ length. The reactor as a rectangular basin is raised from the ground surface about four meters. The first tank consists of three chambers separated with baffles at a distance of $0.4 \mathrm{~m}, 0.3 \mathrm{~m}$, and $0.3 \mathrm{~m}$ with $0.9 \mathrm{~m}$ in width and $1.00 \mathrm{~m}$ in depth (Fig. 3-side view). The outlet is then directed to the second sedimentation tank (Fig. 3 top view). These chambers provide the quiescent condition necessary for the settling process.

The average flow rate of the greywater influent to the sedimentation tank is $225 \mathrm{~L} / \mathrm{hr}$ with a Surface Overflow Rate (SOR) of about $2.5 \mathrm{~m}$ /hour and a retention time of $90 \mathrm{~min}$. This study included the examination of the removal efficiency at different settling times; namely 1.5, 3.0 and $4.5 \mathrm{hr}$. 
The physical and chemical characteristics of the raw greywater were determined on weekly basis. Meanwhile, the physical and chemical characteristics of the examined greywater before and after treatment by batch and pilot-plant studies were carried out according to the Standard Methods of American Public Health Association ${ }^{(26)}$.

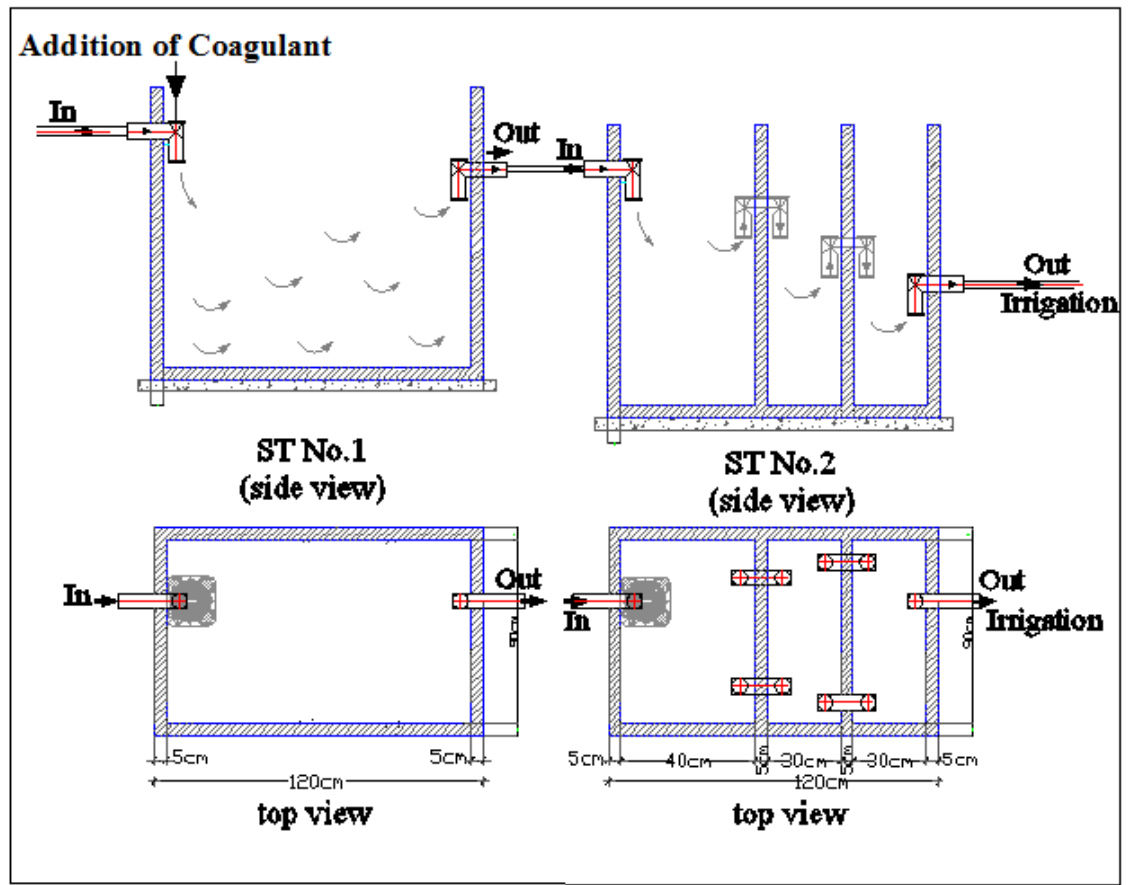

Fig. 3. Schematic diagram of the settling (sedimentation) tanks No.1 and No.2 (side view and top view).

\section{Results and Discussion}

Physical and chemical characteristics of raw greywater

The characteristics of the raw greywater are given in Table 1 . The results show that the concentrations of $\mathrm{COD}, \mathrm{BOD}_{5}$ and oil \& grease are within the high level range. However, the dissolved oxygen is within the low level whereas $\mathrm{pH}$ is at the neutral level. By correlating the characteristics of the raw greywater (Table 1) with the permissible limits (Table 2) it can be seen that such greywater is allowed to be used for irrigating woody trees according to the Egyptian regulation of the "Egyptian Environmental Affairs Authority"(25) without any treatment as $3^{\text {rd }}$ class irrigation water (Table 2).

Egypt. J. Chem. 57, No. 3 (2014) 
TABLE 1. Characteristics of the raw greywater .

\begin{tabular}{|c|c|c|c|c|c|}
\hline Parameter & Unit & $\mathbf{N}$ & $\begin{array}{l}\text { Min. } \\
\text { value }\end{array}$ & $\begin{array}{l}\text { Max. } \\
\text { value }\end{array}$ & Average \\
\hline $\mathrm{pH}$ & --- & 15 & 6.05 & 7.96 & 7.00 \\
\hline Electrical Conductivity (EC) & $\mathrm{ms} / \mathrm{cm}$ & 10 & 520.6 & 906 & 688 \\
\hline Temperature & ${ }^{\circ} \mathrm{C}$ & 10 & 27.93 & 29.02 & 28.47 \\
\hline $\begin{array}{ll}\text { Dissolved } & \text { Oxygen } \\
\text { Concentration (D.O.) } & \\
\end{array}$ & $\begin{array}{l}\mathrm{mg} \\
\mathrm{O}_{2} / 1 \\
\end{array}$ & 10 & 0.89 & 2.43 & 1.35 \\
\hline Total Dissolved Solids (TDS) & $\mathrm{mg} / \mathrm{l}$ & 10 & 313 & 597 & 509.87 \\
\hline Total Suspended Solids (TSS) & $\mathrm{mg} / \mathrm{l}$ & 35 & 70 & 202 & 116 \\
\hline $\begin{array}{l}\begin{array}{l}\text { Chemical } \\
\text { (COD) }\end{array} \\
\end{array}$ & $\begin{array}{l}\mathrm{mg} \\
\mathrm{O}_{2} / 1 \\
\end{array}$ & 35 & 301 & 557 & 388 \\
\hline $\begin{array}{lll}\begin{array}{l}\text { Biological } \\
\left(\mathrm{BOD}_{5}\right)\end{array} & \text { Oxygen } & \text { Demands } \\
\end{array}$ & $\begin{array}{l}\mathrm{mg} \\
\mathrm{O}_{2} / 1\end{array}$ & 35 & 220 & 375 & 298.6 \\
\hline $\mathrm{Ca}$ & $\mathrm{mg} / \mathrm{l}$ & 15 & 151.41 & 437.61 & 290.36 \\
\hline $\mathrm{Mg}$ & $\mathrm{mg} / \mathrm{l}$ & 15 & 83.22 & 140.01 & 105.64 \\
\hline $\mathrm{Na}$ & $\mathrm{mg} / \mathrm{l}$ & 15 & 265 & 420 & 320.98 \\
\hline Total Phosphates (T. P.) & $\mathrm{mg} / \mathrm{l}$ & 15 & 8.4 & 12.1 & 10.54 \\
\hline Nitrates $\left(\mathrm{NO}_{3}\right)$ & $\mathrm{mg} / \mathrm{l}$ & 15 & 0.39 & 0.48 & 0.40 \\
\hline Nitrites $\left(\mathrm{NO}_{2}\right)$ & $\mathrm{mg} / \mathrm{l}$ & 15 & ND & ND & ND \\
\hline Ammonia & $\mathrm{mg} / \mathrm{l}$ & 15 & 7.5 & 9.2 & 8.4 \\
\hline Total Kjeldahl Nitrogen (TKN) & $\mathrm{mg} / \mathrm{l}$ & 15 & 18 & 32 & 28 \\
\hline Oil \& Grease & $\mathrm{mg} / \mathrm{l}$ & 35 & 89 & 296 & 128.5 \\
\hline $\begin{array}{l}\text { Adjusted Sodium } \\
\text { Ratio }\left(\mathrm{SAR}_{\text {adj })}\right.\end{array}$ & $\%$ & 15 & 20.04 & 23.79 & 22.55 \\
\hline
\end{tabular}

$\mathrm{N}=$ Number of samples, $\quad$ Min. = minimum, $\quad$ Max. = maximum

TABLE 2. Permissible limits of water reuse for irrigation according to the Egyptian regulation".

\begin{tabular}{|c|c|c|c|c|}
\hline & & $3^{\text {rd }}$ class & $2^{\text {nd }}$ class & $\mathbf{1}^{\text {st }}$ class \\
\hline Parameter & Unit & $\begin{array}{l}\text { Primary treated } \\
\text { wastewater }\end{array}$ & $\begin{array}{c}\text { Secondary } \\
\text { treated } \\
\text { wastewater }\end{array}$ & $\begin{array}{c}\text { Advanced } \\
\text { treated } \\
\text { wastewater }\end{array}$ \\
\hline $\mathrm{BOD}_{5}$ & $\mathrm{mg} \mathrm{O}_{2} / 1$ & 300 & 40 & 20 \\
\hline COD dichromate & $\mathrm{mg} \mathrm{O}_{2} / \mathrm{l}$ & 600 & 80 & 40 \\
\hline TSS & $\mathrm{mg} / \mathrm{l}$ & 350 & 40 & 20 \\
\hline Oil and Grease & $\mathrm{mg} / \mathrm{l}$ & Not limited & 10 & 5 \\
\hline $\begin{array}{l}\text { Number of cells or } \\
\text { eggs of Nimatoda }\end{array}$ & Count/1 & 5 & 1 & 1 \\
\hline E.Coli count & $100 / \mathrm{ml}$ & Not limited & 1000 & 100 \\
\hline TDS & $\mathrm{mg} / \mathrm{l}$ & 2500 & 2000 & 2000 \\
\hline $\mathrm{Na}$ absorption ratio & $\%$ & 25 & 20 & 20 \\
\hline $\begin{array}{l}\text { Electric } \\
\text { Conductivity }\end{array}$ & $\mu \mathrm{mhos}$ & 750 2000 & $250 \sim 750$ & 250 \\
\hline
\end{tabular}

"Egyptian regulation: (Reference No.25) 


\section{Batch experiments}

Effect of the settling at different times

The examined settling times were 1.5, 3.0 and $4.5 \mathrm{hr}$. Results indicated that the longer the settling time, the highest reduction of pollution parameters (Fig. 4). At the settling time $3.0 \mathrm{hr}$, greywater removal efficiencies reached $65.1 \%, 17.0 \%, 18.5 \%$, and $24.4 \%$ for the TSS, COD, $\mathrm{BOD}_{5}$ and oil \& grease, respectively. By increasing the settling time to $4.5 \mathrm{hr}$, better removal efficiency could be achieved namely; $66.5 \%, 40.3 \%, 38.5 \%$, and $50.2 \%$, successively. TSS results are reported the best achieved removal parameter figures, namely 55.9, 65.1 and $69.77 \%$ at $1.5,3.0$ and $4.5 \mathrm{hr}$ settling time, respectively. It is worth noting that the oil \& grease parameter was mostly removed after $4.5 \mathrm{hr}^{(27)}$.

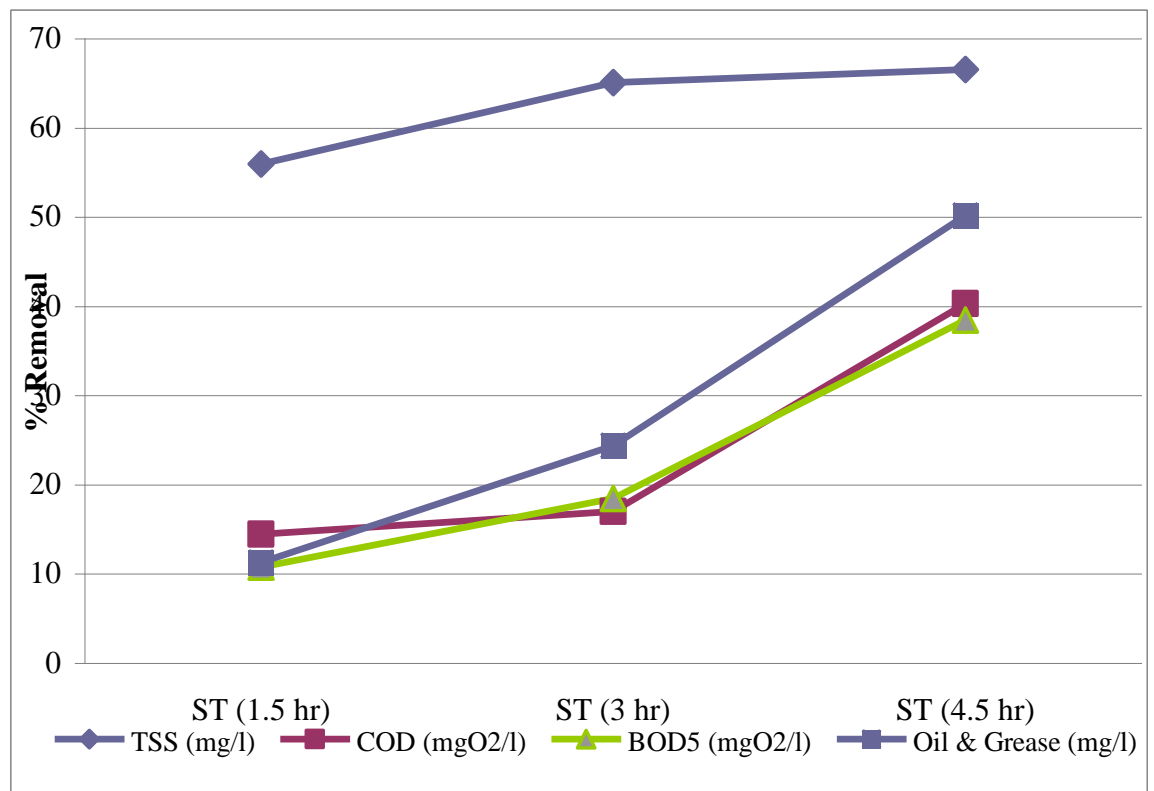

Fig. 4. Effect of settling time on the removal of pollution parameters.

Effect of chemical coagulation

Effect of lime dose: Using the jar-test, variable dose of lime ranging from 5 to $200 \mathrm{mg} / \mathrm{L}$ was examined to determine the optimum dose to serve for the treatment of raw greywater. The results (Fig. 5) indicated that increasing the lime dose improves the removal rates. The optimum dose was found $160 \mathrm{mg} / \mathrm{l}$ at which the removal rate reached $74 \%, 68 \%, 69 \%$, and $86 \%$ for TSS, COD, $\mathrm{BOD}_{5}$, and oil \& grease, respectively (Fig. 5).

Egypt. J. Chem. 57, No. 3 (2014) 


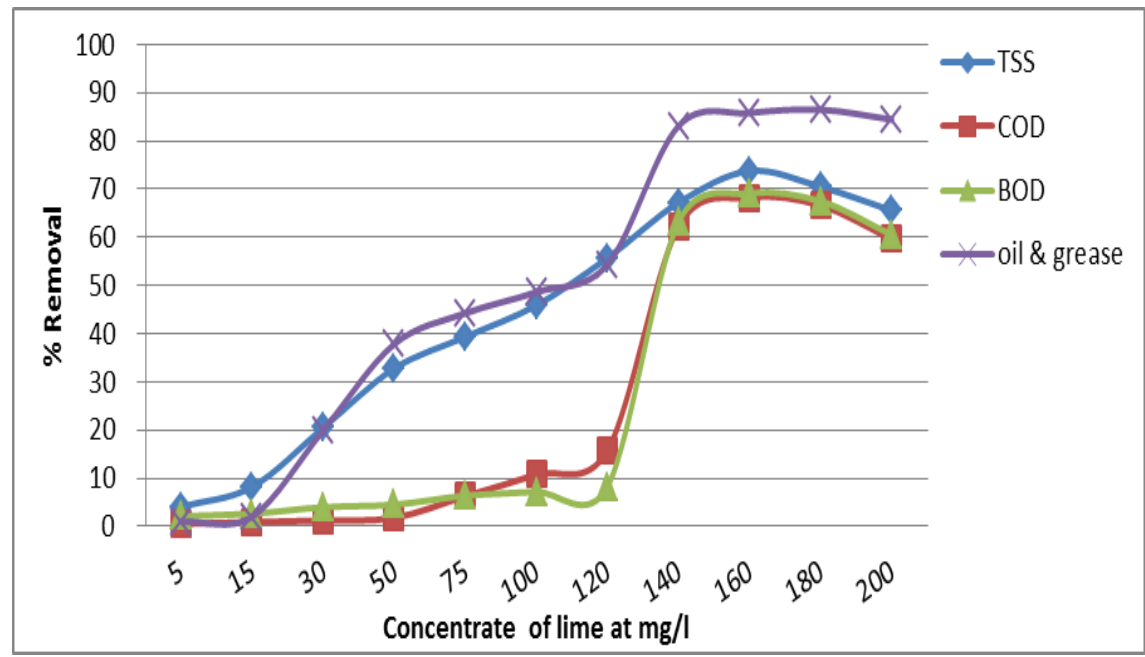

Fig. 5. Effect of variable lime dose on the removal efficiency of raw greywater.

Effect of ferric chloride dose in combination with optimum dose of lime: By employing the jar-test, the predetermined optimum lime dose $(160 \mathrm{mg} / \mathrm{L})$ in combination with different ferric chloride doses ranging from 10 to $120 \mathrm{mg} / \mathrm{L}$ was studied. Results shown in Fig. 6 emphasize that increasing ferric chloride dose increases the removal rates. It is obvious that the ferric chloride optimum dose is $100 \mathrm{mg} / \mathrm{l}$ by which the best removal rate could be reached $98 \%, 83 \%$, $83 \%$, and $95 \%$ for TSS, COD, $\mathrm{BOD}_{5}$ and oil \& grease, respectively (Fig. 6).

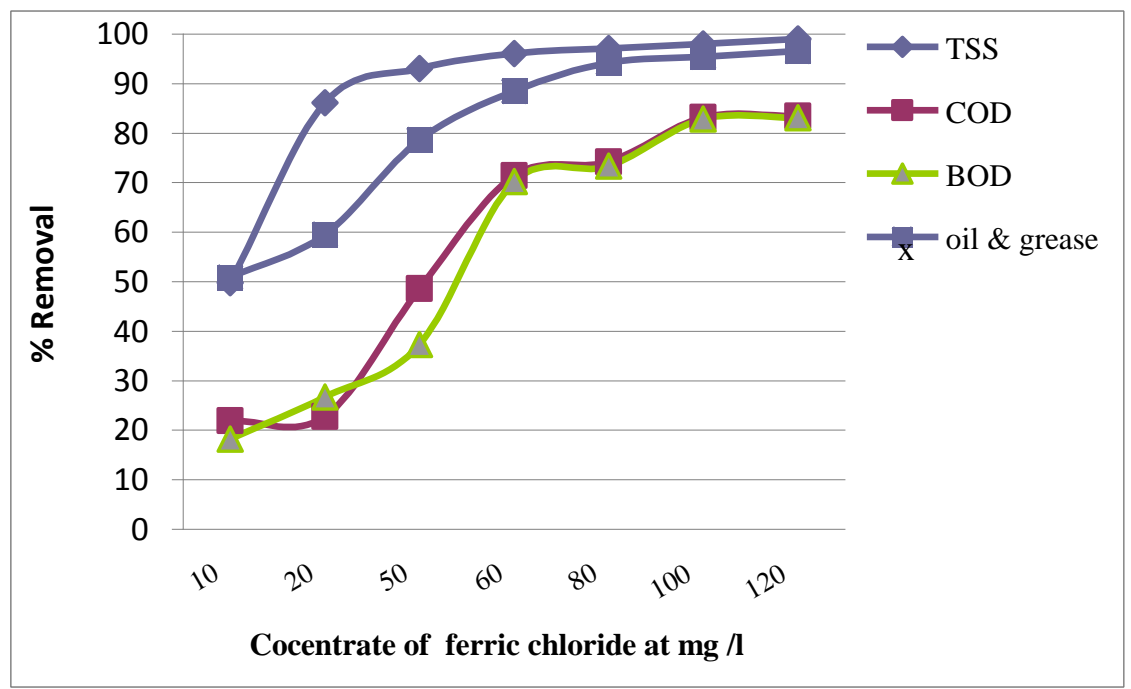

Fig. 6. Effect of variable ferric chloride dose associated with $160 \mathrm{mg} / \mathrm{l}$ lime on the removal efficiency of raw greywater.

Egypt. J. Chem. 57, No. 3 (2014) 


\section{Effect of advanced oxidation (Fenton's reaction)}

Determination of hydrogen peroxide optimum dose: Employing the jar-test and the raw greywater, variable dose of hydrogen peroxide concentration, ranging from 50 to $800 \mathrm{mg} / \mathrm{L}$, was examined at constant dose of ferric sulfate $\left(\mathrm{FeSO}_{4}\right.$ ) namely $130 \mathrm{mg} / \mathrm{L}$. The results (Table 3) indicated that increasing the $\mathrm{H}_{2} \mathrm{O}_{2}$ dose increases the removal rate. It was indicated that the optimum $\left(\mathrm{H}_{2} \mathrm{O}_{2}\right)$ dose is $100 \mathrm{mg} / \mathrm{L}$. The recorded removal rate at the $100 \mathrm{mg} / \mathrm{l} \mathrm{H}_{2} \mathrm{O}_{2}$ was $85 \%, 87 \%, 58 \%$, and $74 \%$ for TSS, COD, $\mathrm{BOD}_{5}$, and oil \& grease, respectively (Table 3).

Determination of ferrous sulfate optimum dose in combination with hydrogen Peroxide : Further study was conducted at the predetermined $\mathrm{H}_{2} \mathrm{O}_{2}$ optimum dose (100 $\mathrm{mg} / \mathrm{L}$ ) with different doses of $\mathrm{FeSO}_{4}$ ranged from 5 to $130 \mathrm{mg} / \mathrm{L}$. The results (Table 4) reveal that the optimum $\mathrm{FeSO}_{4}$ dose is $40 \mathrm{mg} / \mathrm{L}$ at which the removal rate reached $81 \%, 90 \%, 91 \%$, and $75 \%$ for $\mathrm{TSS}, \mathrm{COD}, \mathrm{BOD}_{5}$, and oil \& grease, respectively (Table 4$)$.

\section{Pilot-plant continuous flow studies}

Real greywater as continuous flow in a pilot plant (Fig. 1) was the subject of this study.

Settling of raw greywater for 3.0 and 4.5 hours without any chemical addition

Raw greywater was subjected to settling for a period of 3.0 and $4.5 \mathrm{hr}$ in the sedimentation tanks (Fig. 2). Results (Table 5) indicate that increasing the settling time from 3.0 to $4.5 \mathrm{hr}$ increases the removal rate of TSS, COD, BOD and oil \& grease from $64.5,30.1,19.4$ and $31.7 \%$ to $71.3,25.5,29.6$ and $49.1 \%$, respectively. The characteristics of the treated effluent are still below the permissible limits of the $2^{\text {nd }}$ class water reuse according to the requirements. The poor quality of the effluent can be accounted for the presence of fluffy sludge accumulated through settling as well as suspended solids that could not be easily settled $^{(12,22,28)}$. Therefore, it was crucial to improve this settling process to obtain reasonable water quality for reuse purposes ${ }^{(29)}$.

Addition of lime followed by settling

After adding the predetermined optimum dose of lime, namely $160 \mathrm{mg} / \mathrm{l}$, to the raw greywater in the sedimentation tanks followed by settling for $3.0 \mathrm{hr}$, remarkable removal efficiency was achieved as indicated by TSS, COD, $\mathrm{BOD}_{5}$ and oil \& grease,. The corresponding removal rates were 76, 68, 69, and 85\%, respectively (Table 6).

When the settling time increased to $4.5 \mathrm{hr}$, the removal efficiency increased to $80,72,75$ and $88 \%$ for TSS, COD, $\mathrm{BOD}_{5}$ and oil \& grease, successively (Table 6). By comparing the characteristics of the final effluent with the local permissible limits it can be seen that it is still below the requirement limits of the $2^{\text {nd }}$ class water reuse ( $2^{\text {nd }}$ group secondary wastewater treatment) for irrigation reuse according to the "Egyptian Guideline" (25).

Egypt. J. Chem. 57, No. 3 (2014) 
TABLE 3. Bench-scale study on the effect of $\mathrm{H}_{2} \mathrm{O}_{2}$ dose on the treatment of raw greywater at constant ferrous sulfate dose ( $130 \mathrm{mg} / \mathrm{L}$ ).

\begin{tabular}{|c|c|c|c|c|c|c|c|c|c|c|c|c|c|c|}
\hline \multirow{3}{*}{ Parameter } & \multirow{3}{*}{$\begin{array}{c}\begin{array}{c}\text { Number } \\
\text { or } \\
\text { samples }\end{array} \\
\end{array}$} & \multirow{3}{*}{$\begin{array}{c}\text { Raw } \\
\text { greywater } \\
\text { Con. } \\
\end{array}$} & \multicolumn{12}{|c|}{$\mathrm{H}_{2} \mathrm{O}_{2}$ dose } \\
\hline & & & \multicolumn{2}{|c|}{$50 \mathrm{mg}$} & \multicolumn{2}{|c|}{$100 \mathrm{mg} / \mathrm{A}$} & \multicolumn{2}{|c|}{$200 \mathrm{mg} / \mathrm{A}$} & \multicolumn{2}{|c|}{$400 \mathrm{mg} /$} & \multicolumn{2}{|c|}{$600 \mathrm{mg} / \mathrm{s}$} & \multicolumn{2}{|c|}{$800 \mathrm{mg} / \mathrm{A}$} \\
\hline & & & Con. & $\% \mathrm{R}$ & Con. & $\% \mathrm{R}$ & Con. & $\% \mathrm{R}$ & Con. & $\% \mathrm{R}$ & Con. & $\% \mathbf{R}$ & Con. & $\% \mathrm{R}$ \\
\hline Temper ature ${ }^{\circ} \mathrm{C}$ & 5 & 28.52 & 28.78 & & 28.8 & & 28.83 & & 28.93 & & 29.02 & & 29.11 & \\
\hline $\mathrm{pH}$ & 5 & & 10.2 & - & 10.3 & - & 10.4 & $\ldots$ & 10.38 & & 10.35 & $-\ldots$ & 10.3 & \\
\hline & 5 & & 18 & 74.29 & 10.3 & 85.29 & 68 & 2.86 & 61 & 12.86 & 50 & 28.57 & 46 & 34.29 \\
\hline $\mathrm{COD}\left(\mathrm{mgO}_{2} / \mathrm{l}\right)$ & 5 & 33 & 113 & 66.37 & 43 & 87.20 & 187 & 44.35 & 6 & 41.67 & 212 & 36.90 & 22 & 33.93 \\
\hline $\mathrm{BOD}_{\mathrm{s}}\left(\mathbf{m g O} \mathrm{O}_{2}\right.$ & 5 & 24 & 164 & 33.33 & 103 & 58.13 & 131 & 46 & 134 & 45.53 & 142 & 42.28 & 153 & 37.8 \\
\hline il \& Greas & 5 & 86 & 14 & 83.72 & 22 & 74.42 & 34 & 60.47 & 27 & 68.6 & 16 & 81.40 & 12 & 86.0 \\
\hline
\end{tabular}

TABLE 4. Bench-scale study on the effect of ferrous sulfate dose on the treatment of raw greywater at constant $\mathrm{H}_{2} \mathrm{O}_{2}$ dose ( $100 \mathrm{mg} / \mathrm{L}$ ).

\begin{tabular}{|c|c|c|c|c|c|c|c|c|c|c|c|c|c|c|}
\hline \multirow{2}{*}{ Parameter } & \multirow{2}{*}{$\begin{array}{l}\text { Number } \\
\text { of } \\
\text { ofmples }\end{array}$} & \multirow{2}{*}{$\begin{array}{l}\text { Raw } \\
\text { greywater } \\
\text { com. }\end{array}$} & \multicolumn{12}{|c|}{$\left.\left[\mathrm{Fe}_{2} \text { ( } \mathrm{SO}_{4}\right)_{3}\right]$ ] dose } \\
\hline & & & Con. & $a_{0 R}$ & $c=0$ & $0_{0 R}$ & Con. & $0_{0} \mathbf{R}$ & com & $0_{068}$ & Con & $\frac{n_{0}}{8}$ & $\operatorname{con}$ & 24 \\
\hline Temperature ${ }^{\circ} \mathrm{C}$ & 3 & 20.02 & 29.15 & $\ldots$ & 20.32 & $\cdots$ & 29.5 & $\ldots$ & 20.58 & $-\cdots$ & 29.76 & $\ldots$ & 20.9 & $\cdots$ \\
\hline pH & $s$ & 7.96 & 10.2 & $\ldots$ & 10.31 & $\ldots$ & 10.3 & $\ldots$ & 10.36 & $-\cdots$ & 10.38 & $\ldots$ & 10.4 & $\ldots$ \\
\hline TSS (mg/) & $s$ & 74 & 16 & 78.38 & 4 & 94.6 & 14 & 81.08 & 20 & 72.97 & 21 & 71.62 & 22 & 70.27 \\
\hline $\mathrm{COD}\left(\mathrm{mgO}_{2} / \mathrm{h}\right)$ & 5 & 301 & 102 & 66.11 & 67 & 77.7 & 29 & 90.37 & 69 & 77.08 & 63 & 79.07 & 60 & 80.07 \\
\hline $\mathbf{B O D}_{5}\left(\mathrm{Cmg}_{2} / \mathbf{l}\right)$ & 5 & 220 & 72 & 67.27 & 47 & 78.6 & 19.5 & 91.14 & 43 & 80.45 & 39 & $\begin{array}{lll}82.27 & \\
\end{array}$ & 37 & $\begin{array}{ll}83.18 \\
\end{array}$ \\
\hline OI \& Grease (m $\approx$ 1 & 5 & 196 & 98 & so & so & 74.5 & 48 & 75.51 & 30 & 84.69 & 55 & 71.94 & $\begin{array}{ll}86 \\
\end{array}$ & 56.12 \\
\hline
\end{tabular}


TABLE 5. Pilot plant study on the average characteristics of greywater after settling for 3 and $4.5 \mathrm{hr}$ in absence of chemicals.

\begin{tabular}{|c|c|c|c|c|c|c|c|}
\hline \multirow{2}{*}{ Parameter } & \multirow{2}{*}{$\begin{array}{c}\text { Number } \\
\text { of } \\
\text { samples }\end{array}$} & \multirow{2}{*}{$\begin{array}{c}\text { Raw } \\
\text { greywater } \\
\text { concentration } \\
\text { (average) }\end{array}$} & \multicolumn{2}{|c|}{$\begin{array}{l}\text { Settling Tank } \\
\qquad(3.0 \mathrm{hr})\end{array}$} & \multicolumn{2}{|c|}{$\begin{array}{l}\text { Settling Tank } \\
\text { (4.5 hours) }\end{array}$} & \multirow{2}{*}{$\begin{array}{c}\text { Permissible } \\
\text { limits } \\
2^{\text {nd }} \text { group } \\
\text { for } \\
\text { (secondary } \\
\text { treatment) }^{*}\end{array}$} \\
\hline & & & $\begin{array}{c}\text { Concentr- } \\
\text { ation } \\
\text { (average) }\end{array}$ & $\begin{array}{c}\text { Removal } \\
\%\end{array}$ & $\begin{array}{l}\text { Concenr- } \\
\text { ation } \\
\text { (average) }\end{array}$ & $\begin{array}{c}\text { Rem- } \\
\text { oval } \\
\%\end{array}$ & \\
\hline TSS (mg/l) & 7 & 126.6 & 44.9 & 64.5 & 36.3 & 71.3 & 40 \\
\hline $\mathrm{COD}(\mathrm{mg} / \mathrm{l})$ & 7 & 470.2 & 375.8 & 20.1 & 350.5 & 25.5 & 80 \\
\hline $\mathrm{BOD}(\mathrm{mg} / \mathrm{l})$ & 7 & 346.2 & 279.1 & 19.4 & 243.8 & 29.6 & 40 \\
\hline $\begin{array}{l}\text { Number of cells or } \\
\text { eggs of Nimatoda } \\
(\text { Count/l) }\end{array}$ & 7 & --- & --- & & --- & --- & 1 \\
\hline $\begin{array}{l}\text { E.Coli count } \\
(100 / \mathrm{ml})\end{array}$ & 7 & ND & ND & ---- & ND & --- & 1000 \\
\hline $\begin{array}{l}\text { Oil \& grease } \\
(\mathrm{mg} / \mathrm{l})\end{array}$ & 7 & 124.8 & 85.3 & 31.7 & 63.5 & 49.1 & 10 \\
\hline SAR $(\%)$ & 7 & 20.87 & 19.69 & 5.62 & 19.09 & 8.53 & 20 \\
\hline
\end{tabular}

Egyptian regulation: (Reference No. 25)

$\mathrm{ND}=$ not detected

TABLE 6. Characteristics of greywater after chemical coagulation with lime followed by settling for 3.0 and $4.5 \mathrm{hr}$

\begin{tabular}{|c|c|c|c|c|c|c|c|}
\hline \multirow[t]{2}{*}{ Parameter } & \multirow[t]{2}{*}{$\begin{array}{c}\text { Number } \\
\text { of } \\
\text { samples }\end{array}$} & \multirow{2}{*}{$\begin{array}{c}\text { Raw } \\
\text { greywater } \\
\text { concentration } \\
\text { (average) }\end{array}$} & \multicolumn{2}{|c|}{$\begin{array}{c}\text { Addition of lime } \\
\text { (160 mg/l) followed by } \\
\text { settling for } \\
(3.0 \mathrm{hr})\end{array}$} & \multicolumn{2}{|c|}{$\begin{array}{c}\text { Addition of lime } \\
(160 \mathrm{mg} / \mathrm{l}) \text { followed by } \\
\text { settling for } \\
(4.5 \mathrm{hr})\end{array}$} & \multirow{2}{*}{$\begin{array}{c}\text { Permissible } \\
\text { limits } \\
2^{\text {nd }} \text { group } \\
\text { for } \\
\text { (secondary } \\
\text { treatment) }\end{array}$} \\
\hline & & & $\begin{array}{c}\text { Concentration } \\
\text { (Average) }\end{array}$ & $\begin{array}{c}\text { Removal } \\
\%\end{array}$ & $\begin{array}{c}\text { Concentration } \\
\text { (average) }\end{array}$ & $\begin{array}{c}\text { Removal } \\
\% \\
\end{array}$ & \\
\hline TSS (mg/l) & 7 & 101.33 & 24.67 & 75.66 & 19.77 & 80.49 & 40 \\
\hline $\mathrm{COD}(\mathrm{mg} / \mathrm{l})$ & 7 & 399.67 & 126 & 68.47 & 111.5 & 72.10 & 80 \\
\hline BOD (mg/l) & 7 & 256 & 78.67 & 69.27 & 63.7 & 75.12 & 40 \\
\hline $\begin{array}{l}\text { Number of cells or } \\
\text { eggs of Nimatoda } \\
(\text { Count/l) }\end{array}$ & 7 & ND & ND & ND & ND & ND & 1 \\
\hline $\begin{array}{l}\text { E. Coli count } \\
(100 / \mathrm{ml})\end{array}$ & 7 & --- & --- & --- & --- & --- & 1000 \\
\hline Oil \& grease $(\mathrm{mg} / \mathrm{l})$ & 7 & 163.67 & 24.83 & 84.83 & 18.5 & 88.70 & 10 \\
\hline $\operatorname{SAR}(\%)$ & 7 & 20.04 & 17.9 & 10.68 & 16.5 & 17.66 & 20 \\
\hline
\end{tabular}

*Egytian regulation: Reference No. 25

$\mathrm{ND}=$ not detected

Egypt. J. Chem. 57, No. 3 (2014) 
TABLE 7. Characteristics of greywater after chemical coagulation with lime in combination with ferric chloride followed by settling for 3.0 and $4.5 \mathrm{hr}^{*}$.

\begin{tabular}{|c|c|c|c|c|c|c|c|}
\hline \multirow[t]{2}{*}{ Parameter } & \multirow[t]{2}{*}{$\begin{array}{c}\text { Number } \\
\text { of } \\
\text { samples }\end{array}$} & \multirow[t]{2}{*}{$\begin{array}{l}\text { Raw Greywater } \\
\text { concentration } \\
\text { (Average) }\end{array}$} & \multicolumn{2}{|c|}{$\begin{array}{c}\text { Addition of lime } \\
\text { (160 mg/l) and ferric } \\
\text { chloride }(100 \mathrm{mg} / \mathrm{l}) \\
\text { followed by settling for } \\
(3.0 \mathrm{hr})^{*}\end{array}$} & \multicolumn{2}{|c|}{$\begin{array}{c}\text { Addition of lime } \\
(160 \mathrm{mg} / \mathrm{l}) \text { and ferric } \\
\text { chloride }(100 \mathrm{mg} / \mathrm{l}) \\
\text { followed by settling for } \\
(4.5 \mathrm{hr})^{*}\end{array}$} & \multirow{2}{*}{$\begin{array}{l}\text { Permissible } \\
\text { limits } \\
\mathbf{3}^{\text {rd }} \text { group } \\
\text { for } \\
\text { (advanced } \\
\text { treatment) }\end{array}$} \\
\hline & & & $\begin{array}{c}\text { Concentration } \\
\text { (Average) }\end{array}$ & \begin{tabular}{|c|} 
Removal \\
$\%$
\end{tabular} & $\begin{array}{c}\text { Concentration } \\
\text { (Average) }\end{array}$ & $\begin{array}{c}\text { Removal } \\
\%\end{array}$ & \\
\hline $\operatorname{TSS}(\mathrm{mg} / \mathrm{l})$ & 7 & 111.67 & 7.33 & 93.43 & 5.75 & 94.85 & 20 \\
\hline COD (mgl) & 7 & 434.33 & 79.67 & 81.66 & 35.67 & 91.79 & 40 \\
\hline $\mathrm{BOD}(\mathrm{mg} / \mathrm{l})$ & 7 & 309.33 & 38 & 87.72 & 18 & 94.18 & 20 \\
\hline $\begin{array}{c}\text { Number of cells or eggs of } \\
\text { Nimatoda (count } 1 \text { ) }\end{array}$ & 7 & ND & ND & ND & ND & ND & 1 \\
\hline E.Coli count $(100 / \mathrm{ml})$ & 7 & --- & -- & -- & --- & -- & 100 \\
\hline Oil \& greaser (mg/) & 7 & 177 & 9.5 & 94.63 & 5 & 97.17 & 5 \\
\hline SAR $(\%)$ & 7 & 23.79 & 21.4 & 10.02 & 19 & 20.13 & 20 \\
\hline
\end{tabular}

${ }^{*}$ Dose of lime $=160 \mathrm{mg} /$, dose of ferric chloride $=100 \mathrm{mg} / \mathrm{l}$

**:Egytian regulation: Reference No. 25

$\mathrm{ND}=$ not detected 
Addition of lime in combination with ferric chloride followed by settling

Addition of lime in combination with ferric chloride at the predetermined optimum doses $(160 \mathrm{mg} / \mathrm{l}$ lime and $100 \mathrm{mg} / \mathrm{l} \mathrm{FeCl}$ ) was examined followed by settling for $3.0 \mathrm{hr}$. The removal rate reached 93.4, 81.6, 87.7 and $94.6 \%$ for TSS, COD, BOD and oil \& grease, respectively (Table 7). The characteristics of the final effluent could cope with the permissible limits of the $2^{\text {nd }}$ class water reuse ${ }^{(25)}$.

By increasing the settling time to $4.5 \mathrm{hr}$, further increase in the removal rates was remarkably achieved (Table 7). The removal rates reached 94.9, 91.8, 94.2 and $97.2 \%$ for TSS, COD, BOD and oil \& grease, successively (Table 7). The characteristics of the final effluent decreased to $5.8,35.7,18.0$ and $5.0 \mathrm{mg} / \mathrm{l}$, respectively. It is worth noting that the characteristics of this final effluent are within the permissible level of the $1^{\text {st }}$ class (advanced treated wastewater) as a sustainable approach for non-restricted water reuse according to the "Egyptian Guideline" ${ }^{(25)}$.

\section{Conclusions}

1. When the kitchen outflow water is included in greywater then relatively high amount of oil \& grease as well as increasing amount of COD and BOD is expected. Therefore, it is recommended to avoid connecting the kitchen outflow to the greywater.

2. Increasing the settling time remarkably increases the achieved removal rate of the pollution parameters.

3. Addition of lime associated with ferric chloride to the raw greywater could effectively enhance the settling process.

4. When $160 \mathrm{mg} / \mathrm{l}$ lime was added to the raw greywater followed by $3.0 \mathrm{hr}$ settling time improvement was achieved. The characteristics of the final effluent nearly reached the permissible level $2^{\text {nd }}$ class (secondary wastewater treatment) for irrigation reuse according to the "Egyptian Guideline".

5. Using ferric chloride at a level of $100 \mathrm{mg} / \mathrm{l}$ aided with lime dose of $160 \mathrm{mg} / \mathrm{l}$ followed by $4.5 \mathrm{hr}$ settling time, the final effluent could cope with the permissible level of $1^{s t}$ class (advanced treated wastewater) as non-restricted water reuse according to the "Egyptian Guideline". It is worth mentioning that iron is precipitated as sludge and remaining amount of iron is limited. On the other hand, iron is considered a nutrient element to soil and plant at low concentration.

6. It has been concluded that chemical coagulation could successfully approach the objectives of the suggested treatment process. Therefore, it saves any further treatment (i.e. saves the burden of space, energy or labor).

7. Greywater reuse presents a potential option for water demand management that can contribute to the reduction of freshwater consumption for irrigation, particularly in the remote and decentralized areas.

Egypt. J. Chem. 57, No. 3 (2014) 
Acknowledgement: The authors wish to express their deep appreciation to the National Research Centre, Water Research \& Pollution Control Department for the facilities provided to the entire work of the present study. Sincere acknowledgement also goes to Ministry of Higher Education and Scientific Research of Iraq, Qadisiyah University for the financial support of Eng. Ahmed Al-Sulaiman.

\section{References}

1. March, J.G., Gual, M. and Orozco, F., Experience on greywater re-use for toilet flushing in a hotel (Mallorca Island, Spain). Desalination, 164, 241-247 (2004).

2. Nolde, E., Greywater recycling systems in Germany-results, experiences and guidelines. Water Sci. Tech. 51, 203-210 (2005).

3. Nolde, E., Greywater reuse systems for toilet flushing in multi - storey buildings over ten years experience in Berlin. Urban Water, 1, 275-84 (1999).

4. Jefferson, B., Palmer, A., Jeffrey, P., Stuetz, R. and Judd, S., Grey water characterization and its impact on the selection and operation of technologies for urban reuse. Water Sci. Technol. 50 (2), 157-164 (2004).

5. Abdel-Shafy, H.I. and Ahmed Dewedar, Constructed wetlands for urban wastewater treatment in Egypt. J. Sustainable Sanitation Practice, 12, 27-32 (2012).

6. Dallas, S., Scheffe, B. and Ho, G., Reed beds for greywater treatment- Case study in Santa Elena- Monteverde, Costa Rica, Central America. Ecological Engineering, 23, 55-61 (2005)

7. Ramon, G., Green, M., Semiat, R. and Dosoretz, D., Low strength greywater characterization and treatment by direct membrane filtration. Desalination, 170, 241-250 (2004).

8. Abdel-Shafy, H.I. and El-Khateeb, M.A., Integration of Septic tank and constructed wetland for the treatment of wastewater in Egypt. J. Desalination and Water Treatment, Taylor \& Francis Publisher, 51, Issue 16-18 (2013).

9. Masi, F., El Hamouri, B., Abdel Shafi, H., Baban, A., Ghrabi, A. and Regelsberger, M., Treatment of segregated black/grey domestic wastewater using constructed wetlands in the Mediterranean basin: the Zer0-m Experience. Water Science and Technology, 61 (1), 97-105, 2010. doi:10.2166/wst. 2010.780 (2010).

10. Abdel-Shafy, Hussein I., El-Khateeb, M.A., Regelsberger, M., El-Sheikh, R. and Shehata, M. Integrated system for the treatment of blackwater and greywater via UASB and constructed wetland in Egypt. Desalination and Water Treatment, 8,1-7 (2009).

11. Friedler, E. and Alfiya, Y., Physicochemical treatment of office and public buildings greywater. Water Sci. Technol. 62 (10), 2357-2363 (2010).

12. Abdel-Shafy, H.I., Precipitation of $\mathrm{Ni}, \mathrm{Cu}$ and $\mathrm{Mn}$ from industrial wastewater by chemical coagulation. Bull. National Research Center, 17(3), 153-160 (1992).

Egypt. J. Chem. 57, No. 3 (2014) 
13. Wheatley, A.D. and Surendran, S., The design and operation of a grey water treatment plant. In: Advances in Water Supply Management, Maksimovich, C., Butler, D. and Memon, F.A. (Ed), Chapter 7, A.A. Balkema Publishers, pp. 535-544 (2003).

14. Elmitwalli, T.A. and Otterpohl, R., Anaerobic biodegradability and treatment of grey water in upflow anaerobic sludge blanket (UASB) reactor. Water Res. 41, 13791387 (2007).

15. Sriwiriyarat, T. and Jangkorn, S., Evaluation of waste activated sludge as a coagulant aid for the treatment of industrial wastewater containing mixed surfactants. J Environ . Sci. Health A Tox. Hazard Subst . Environ. Eng. Apr. 44 (5), 507- 514 (2009).

16. Li, F., Wichmann, K. and Otterpohl, R., Review of the technological approaches for grey water treatment and reuses. Science of the Total Environment, 407, 34393449 (2009).

17. El-karamany, H., Study for industrial wastewater treatment Using some coagulants. Fourteenth International Water Technology Conference, IWTC 14 Cairo, Egypt (2010).

18. McArdell, C.S., Molnar, E., Suter, M.J.F., Giger, W., Occurrence and fate of macrolide antibiotics in wastewater treatment plants and in the Glatt Valley Watershed, Switzerland. Environmental Science and Technology, 37 (24), 5479-5486. http://dx.doi.org/10.102/es034368i (2003).

19. Friedler, Eran, Katz, Ilan, Dosoretz and Carlos G., Chlorination and coagulation as pretreatments for greywater desalination. Desalination, 222, 38-49 (2008).

20. Song, Z, William, C.J. and Edyvean, R.G.J., Treatment of tannery wastewater by chemical coagulation. Desalination, 164 (3), 249-259 (2004).

21. Rubi, H. and Fall, C., Pollutant removal from oily wastewater discharged from car washes through sedimentation-coagulation. Water Sci. Tech. 59 (12), 2359-2369 (2009).

22. Abdel-Shafy, H.I., El-Khateeb, M.A. and Shehata, M., Greywater treatment using different designs of sand filters. J. Desalination and Water Treatment, Taylor \& Francis Publisher, http://dx.doi.10.1080/19443994.2013.813007 September,1-6 (2013).

23. Abdel-Shafy, H.I. and El-Khateeb, M.A., Membrane bioreactor for the treatment of municipal blackwater in Egypt. J. Desalination and Water Treatment, 29 (1-3), 56-62 (2011).

24. Wee Hong Chin, A Thesis submitted in fulfillment of the requirements for the degree of Doctor of Philosophy: 'Greywater Treatment by Fenton, Photo-Fenton and UVC/H2O2 Processes'; School of Civil, Environmental and Chemical Engineering RMIT University, Melbourne. March (2009).

25. Egyptian Environmental Affairs Authority (EEAA) - Egyptian regulation: Law 48, No. 61-63, Permissible values for wastes in River Nile (1982) and Law 9, Law of the Environmental Protection (2009).

Egypt. J. Chem. 57, No. 3 (2014) 
26. APHA, AWWA and WEF, Standard Methods for the Examination of Water and Wastewater, $21^{\text {st }}$ ed., American Public Health Association, Washington, DC, (2006), http://www.standardmethods.org/.

27. Abdel-Shafy, Hussein, I., Al-Sulaiman, A.M. and Mansour, Mona S.M., Greywater treatment via hybrid integrated systems for unrestricted reuse in Egypt. J. Water Process Eng. 1, 101-107 (2014), http://dx.doi.org/10.1016/j.jwpe.2014.04.001

28. Abdel-Shafy, H.I., Inka Hobus and Werner Hegemann, Upgrading of decentralized ponds for municipal wastewater treatment and restricted reuse. J. Water Reuse and Desalination, 01(3), 141-151 (2011).

29. Abdel-Shafy, H.I. and Mansour, Mona S.M., Overview on water reuse in Egypt: Present and Future. J. Sustainable Sanitation Practice, 14, 17-25 (2013).

(Received 26/6 / 2014; accepted $7 / 7 / 2014$ )

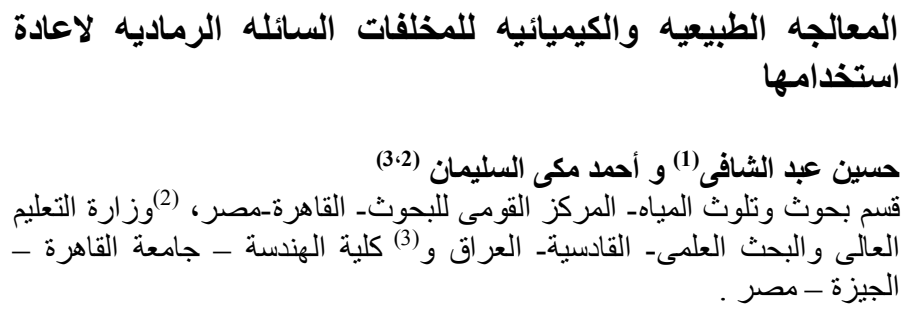

الدر اسه الحاليه تعامل مع مياه رماديه حقيقيه نم تجميعها من منزل مقابل للموقع الإبه

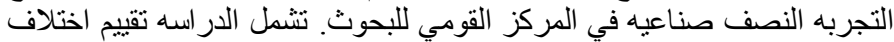

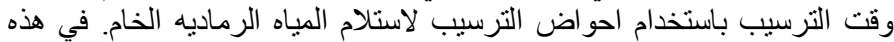

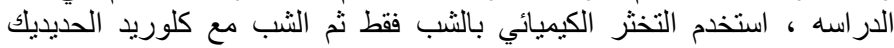

بجر عات مختلفه ، كما تم اختبار الاكسده المتقدمه ( Fenton's reaction).

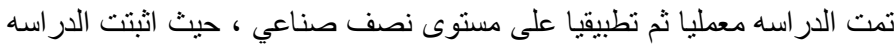

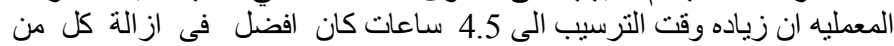

$66.5 \%, 40.3 \%, 38.5 \%$, and $50.2 \%$, for the TSS, COD, BOD 5

and oil \& grease

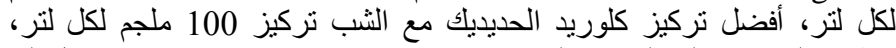

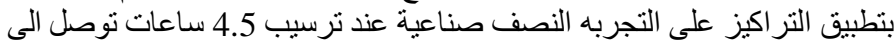

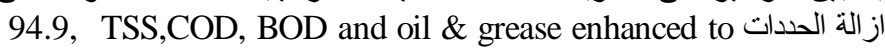
91.8, 94.2 and 97.2\%,

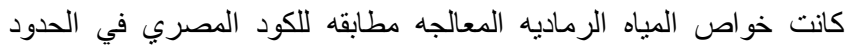

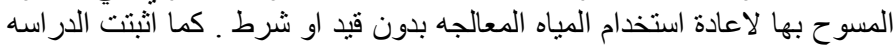

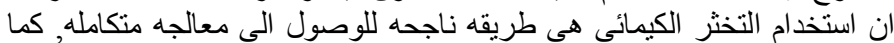

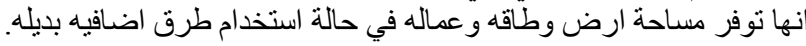

